\title{
The One Health approach for the management of an imported case of rabies in mainland Spain in 2013
}

A C Pérez de Diego (anacristina@sanidadanimal.info) ${ }^{1}$, M Vigo $^{2}$, J Monsalve ${ }^{2}$, A Escudero² $^{2}$

1. Livestock Department (Epidemiology), Environmental Management of Castilla-La Mancha (GEACAM), Department of Agriculture, Government of Castilla-La Mancha, Toledo, Spain

2. General Directorate of Agricultural and Livestock, Department of Agriculture, Government of Castilla-La Mancha, Toledo, Spain

Pérez de Diego AC, Vigo M, Monsalve J, Escudero A. The One Health approach for the management of an imported case of rabies in mainland Spain in 2013 . Euro Surveill. 2015;20(6):pii=21033. Available online: http://www.eurosurveillance.org/ViewArticle.aspx?Articleld=21033

After more than 30 years without any reported cases of rabies in terrestrial carnivores in mainland Spain, an imported case was detected in June 2013 in Toledo. Although the infected dog was moved across different locations and had contact with humans and dogs, the incident was controlled within a few days. An epidemiological investigation was performed and rabiesfree status in terrestrial carnivores in mainland Spain was restored six months after the incident. Key to the successful management of this case were the previous vaccination of susceptible animals in the affected area before the case was detected, the collaboration of different authorities in decision making, and the application of control measures according to national and international regulations and to the One Health concept.

\section{Background}

In the 2oth century, mainland Spain suffered continuous outbreaks of rabies until 1966, when the country was declared free of rabies for the first time. In 1975 , a new outbreak occurred in Malaga in southern Spain which was started by an infected dog owned by a tourist. The disease spread to 81 confirmed animal cases (dogs and cats), leading to the destruction of more than 10,000 dogs within one year. Rabies also caused three human deaths between 1975 and 1978 [1]. Since 1978, mainland Spain has been considered free of rabies in terrestrial carnivores; however, every year, the autonomous cities of Ceuta and Melilla report rabies cases, most imported from Morocco. In 2012, five cases were reported in these cities [2]. Some sporadic cases in bats have been reported since 1987 [3]. The eradication programme in Spain succeeded thanks to the elimination of suspicious animals and vaccination of susceptible animals.

Taking into account the distribution of rabies across the world according to data from the World Organization for Animal Health (OIE), summarised in Figure 1, it was essential for Spain and the European Union (EU) to use risk analysis for the potential introduction of domestic rabies. Several studies were conducted for this purpose [4-6]. This research concluded that the most vulnerable entry route would be the introduction of domestic dogs from Morocco [6]. When border surveillance is working correctly, the probability of importation of the disease decreases considerably, but the possibility of illegal entry of people and animals from Morocco should be taken into account. This is not surprising seeing as sporadic imported cases have been reported in other EU countries, for example recently in France and the Netherlands $[7,8]$.

Since there is no clinical treatment for this zoonotic disease, and only prevention by vaccination is possible public and animal health authorities such as the OIE, recommend the vaccination of domestic animals to avoid the spread of rabies. However, in Spain, mandatory legislation about animal vaccination against rabies is the responsibility of the regional administration, not the national government. Some regions require mandatory vaccination of dogs, and in some places cats are also vaccinated. In some cases mandatory vaccination is annual, in others biennial, and in some autonomous communities it is not mandatory (Figure 2).

\section{Chronology of the event}

In Castilla-La Mancha, a region in mainland Spain, the vaccination programme has changed over time. Since 2002, when there were no rabies cases, vaccination has been voluntary, but in June 2012, the regional government introduced mandatory biennial vaccination [10]. In 2013 an imported case was detected in a dog in Argés, Toledo. The epidemiological investigation established the following sequence of events:

On 1 December 2012, the four year-old Spanish dog was vaccinated, for first time, against rabies with one dose of a polyvalent vaccine. On 12 December 2012, the dog travelled from Spain to an endemic area (Morocco). The time since vaccination was too short for immune protection to develop (the manufacturer's instructions describe the beginning of the immunity three weeks 


\section{FIGURE 1}

Rabies presence by country, 2012

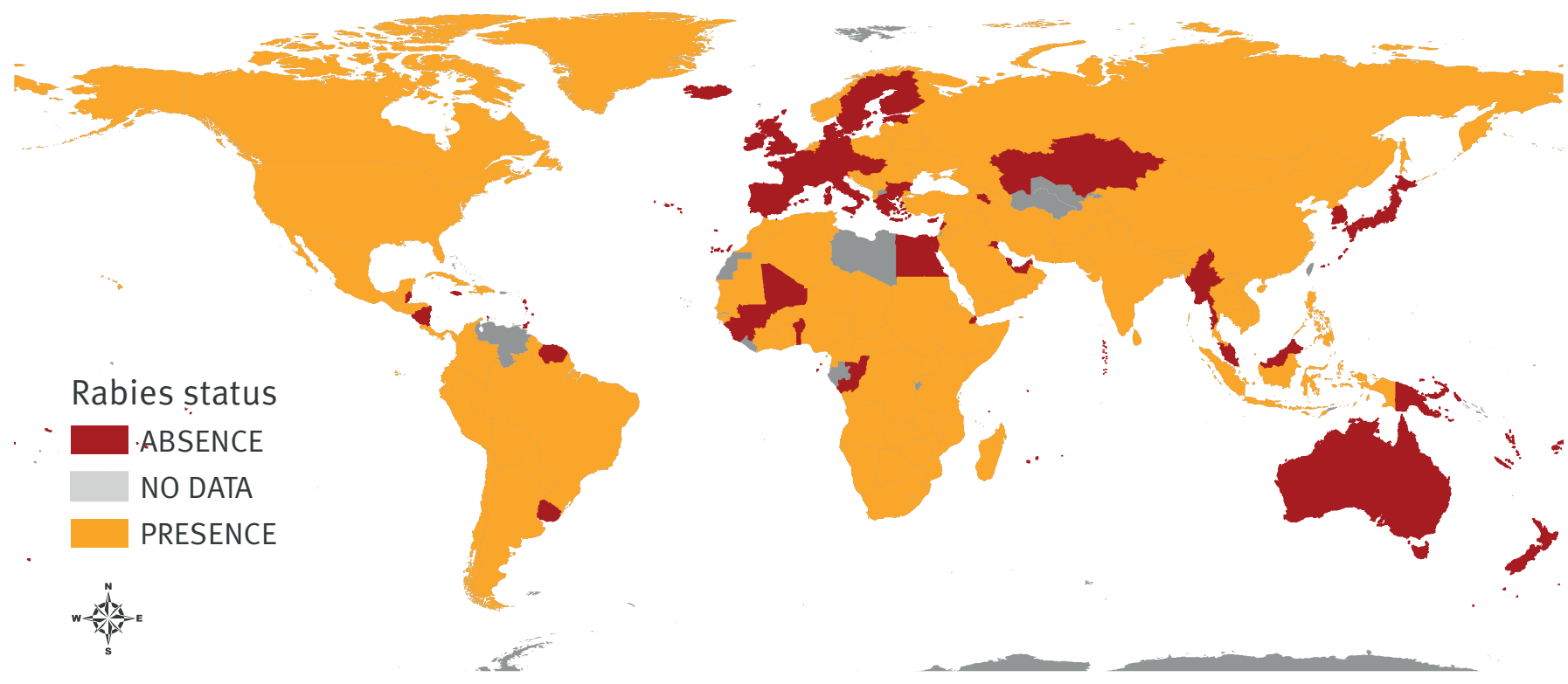

The information includes only the data reported to the World Organization for Animal Health [9], therefore information was not available for all countries in 2012 .

\section{FIGURE2}

Rabies vaccination strategy for dogs in different autonomous communities, Spain, 2012

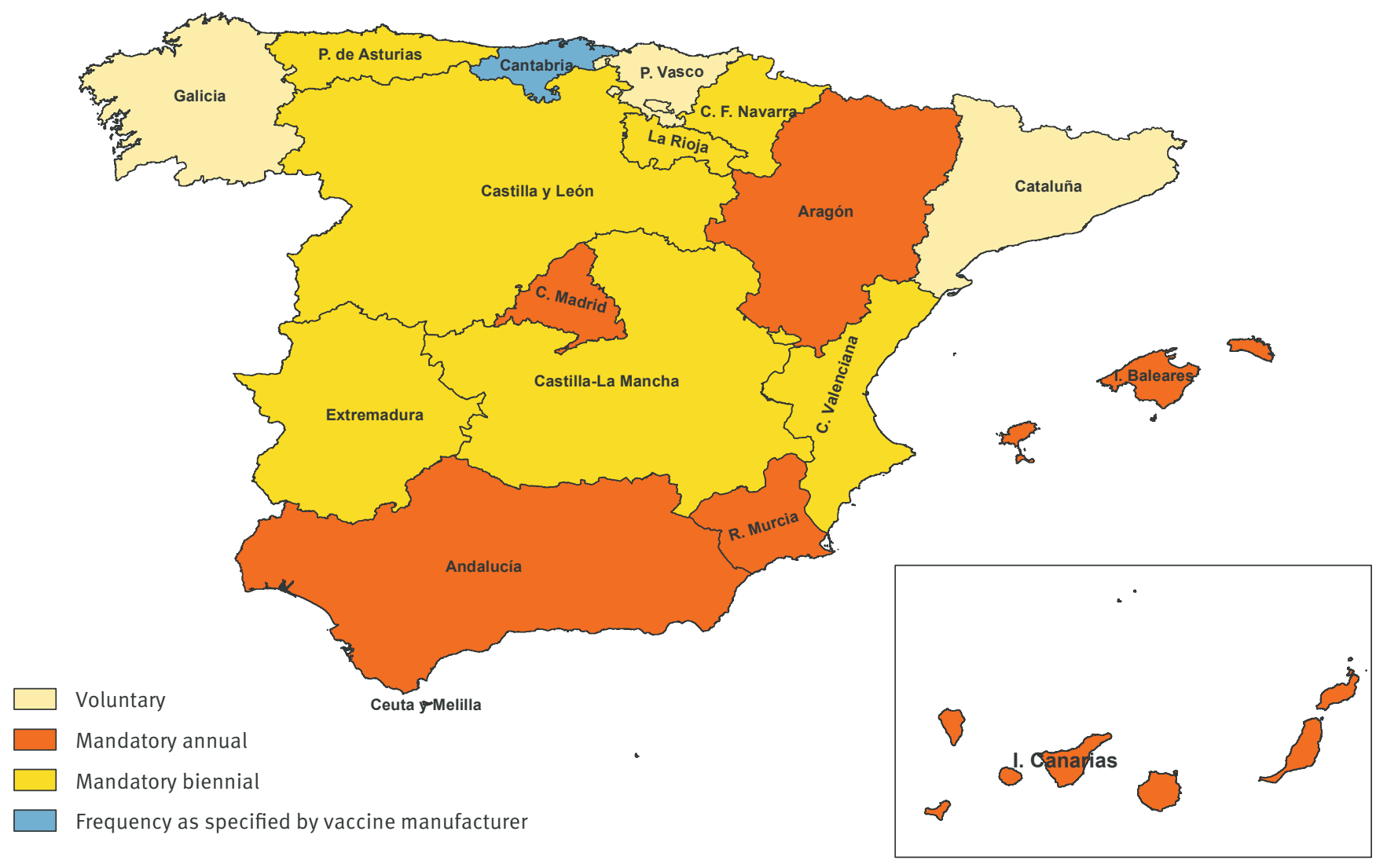


after vaccination and the European regulation requires a period of thirty days between vaccination and seroneutralisation test [11]). On 12 April 2013, the dog returned to Spain. The entry route is unknown, but it is suspected that it was an illegal entry across the border at Ceuta [12]. Earlier, in February, the dog's owners had tried to cross the border legally, but were denied entry because the seroneutralisation assay according to EU regulation [11] had not been done before the trip to Morocco [13].

The dog's owners remained in Catalonia (Barcelona and Piera) until 5 May 2013, then continued to Huesca (Monzón), and returned to Catalonia (Banyoles y Porqueres) on May 18. From 20 to 22 May, they stayed in Barcelona and thereafter in Argés in Toledo province [14]. On 1 June, the dog escaped and attacked four children and one adult in different parts of Toledo. After several attempts to capture the dog and because of its aggressiveness, the police decided to shoot it. The body was retained and according to the protocol for suspicion of rabies, public health authorities sent the head to the national reference laboratory at the National Centre of Microbiology for diagnosis on 3 June 2013. On 5 June, rabies was confirmed by direct immunofluorescence and PCR. The laboratory further identified the genetic profile of the rabies virus as one of the strains circulating in in Morocco.

On 6 June, according to the Spanish contingency plan for rabies [5], a crisis committee was convened to evaluate and establish control measures which included mandatory vaccination of all susceptible domestic animals (dogs, cats and ferrets) in restriction areas; these were areas where the affected dog had been present during the virus excretion period and that were therefore defined as at risk of disease occurrence. Further control measures included restricted movement of susceptible animals, improved control of stray dogs, active surveillance of dogs and their correct vaccination and identification status, and rabies vaccination for people exposed to the infected dog and people who could have otherwise been exposed to the virus [5]. The virus excretion period was assumed to be from 8 May to 1 June, but to ensure the detection of all potential contacts, the period was extended back to 1 May. The four children and the adult that were attacked by the rabies-positive dog on 1 June received post-exposure treatment with human rabies immunoglobulin (HRIG) and rabies vaccine.

The case data, alert status, and adopted measures were reported to all veterinarians who might know about possible dog contacts. In Castilla-La Mancha, all dogs that were potential contacts were placed in an animal health authority facility on 8 June 2013, (nine dogs). All dogs that could have had contact with the infected animal were serologically examined to ensure their vaccination status. One immunosuppressed dog with insufficient protection against rabies was identified as a high risk for transmission. According to the contingency plan, the immunosuppressed dog was sacrificed on 21 June to prevent rabies dissemination [15].

After six months without new cases, rabies-free status for terrestrial carnivores was restored in Spain in December $2013[16,17]$. Many authorities and institutions were involved in this crisis management. Some of them, such as the veterinary association, the Melilla Government or the Spanish Agency for Medicines and Health Products (AEMPS), were not initially included in the contingency plan (Table 1), but were crucial for the resolution of the incident.

In terms of risk perception, it is important to note that at the beginning of this rabies episode, the population reported many stray dogs, dog attacks, and suspicions

TABLE 1

Institutions and agents involved in rabies crisis management, Spain, 2012-13

\begin{tabular}{|c|c|c|c|}
\hline Type of institution & Name & $\begin{array}{c}\text { Foreseen in } \\
\text { contingency plan }\end{array}$ & Field of work \\
\hline \multirow{3}{*}{ National Administration } & MAGRAMA & Yes & Animal health \\
\hline & MSSSI & Yes & Public health \\
\hline & National Reference Laboratory-ISCIII & Yes & Laboratory assays \\
\hline Spanish Medical Agency & AEMPS & No & To ensure sufficient vaccine \\
\hline \multirow{3}{*}{$\begin{array}{l}\text { Regional Administration } \\
\text { (Castilla-La Mancha, Aragón, } \\
\text { Cataluña and Madrid) }\end{array}$} & Department of Agriculture & Yes & Animal health \\
\hline & Department of Health & Yes & Public health \\
\hline & Melilla government & No & Advisor to authorities \\
\hline \multirow{2}{*}{ Security agents } & SEPRONA & Yes & \multirow{2}{*}{ Animal and proprietary identification } \\
\hline & Local police department & Yes & \\
\hline \multirow{3}{*}{ Professionals and experts } & Veterinary association & No & To report new data to veterinarians \\
\hline & Private veterinarians & No & To detect potential contact \\
\hline & VISAVET, other scientific experts & Yes & Advisor to authorities \\
\hline
\end{tabular}

AEMPS: Spanish Agency for Medicines and Health Products; ISCIII: Institute of Health "Carlos III"; MAGRAMA: Ministry of Agriculture, Food and Environment; MSSSI: Ministry of Health; SEPRONA: Nature Protection Service of the Civil Guard; VISAVET: Health Surveillance Centre. 
of rabies after a dog's deaths. All these cases were analysed and no rabies was detected. The social alarm gradually decreased within a few weeks to a residual level similar to the one that exists when no case has been reported in years.

As a preventive measure, people at risk were vaccinated; in Castilla-La Mancha, about 300 people were considered at risk during the event surveillance period until the end of December 2013. Although only 12 people in Castilla-La Mancha could be considered at risk according to the World Health Organization (WHO) category III, 118 people received the complete post-exposure treatment of HRIG and vaccination in this region (Table 2).

\section{Evaluation of management and recommendations}

Although more than 15 different institutions, agents and authorities were involved, communication was immediate and complete from the moment disease was suspected. The effective communication allowed to prevent the potential spread of rabies in Spain, when consequences could have been as severe as in the outbreak of 1975 [1]. The successful collaboration underlines the importance of the One Health concept in preventing emerging disease and the spread of infectious animal disease that could have a significant impact on public health, animal health and national economics [18].

It is important to take into account that the animals involved in this rabies incident were pets. When working in animal health, one of the first measures is to restrict movement of susceptible animals and trade, and to review the most recent movements of the animal involved. When the disease affects pets, all these measures become far more complicated because in contrast to livestock, there is no registration system for the movement of pets. The Veterinary Association

\section{TABLE 2}

Exposure category of human contacts, and post-exposure protocol adopted in Castilla-La Mancha, Spain, 2012-13 $(n=378)$

\begin{tabular}{|c|c|}
\hline & Number of people \\
\hline \multicolumn{2}{|l|}{ WHO category } \\
\hline Type I & 321 \\
\hline Type I/II & 37 \\
\hline Type II & 8 \\
\hline Type III & 12 \\
\hline \multicolumn{2}{|l|}{ Post-exposure treatment } \\
\hline Vaccination & 64 \\
\hline HRIG and vaccination & 118 \\
\hline No treatment administered & 188 \\
\hline No data available & 8 \\
\hline
\end{tabular}

HRIG: human rabies immunoglobulin; WHO: World Health Organization. played an essential role in making information available to the general population and veterinarians, which underlines the importance of establishing an efficient collaboration system between public and private veterinarians and public health authorities.

One of the crucial points in the management of this imported case and its control was the mandatory vaccination ordered in 2012 in the most affected region Castilla-La Mancha, which led to most dogs in this region being vaccinated against rabies. All nine contact dogs in Castilla-La Mancha had been vaccinated in the twelve months previous to the rabies incident. Since vaccination is essential in the prevention of rabies $[19,20]$, it is crucial to establish national legislation for this. It would be useful to require vaccination across the EU not only for movement purposes. Also, it is important to control the movements of pets and comply with the existing regulation, including rabies vaccination of all carnivores entering the EU, especially in areas that have been declared rabies free $[4,21]$.

This case demonstrates how the One Health concept must enlist collaboration from different scientific disciplines [22]. Educating the general population about the importance of pet vaccination could prevent a mortal disease not only of animals but also of humans, and make them participants and collaborators in providing epidemiological data when an outbreak of an emerging disease happens. It is also crucial to educate the population about the risks related to the illegal introduction of pets to the EU and about the appropriate measures to take when travelling to endemic countries. Considering that the infected dog in this report was in fact vaccinated but travelled to Morocco before the immune protection was established, it is important that veterinarians emphasise the necessity to observe correct timing between vaccination and travel to endemic areas. Globalisation comes with the continuous movement of people, animals, products and, consequently, diseases. It is essential to stay alert for the potential risk of disease entry at all times. In the EU, border controls have become more important because a European citizen, once returned from a third country into the EU, could travel across the Schengen area without restriction.

Finally, it is relevant to note the importance of having reference laboratories with updated diagnostic assays and trained personnel who can respond to an alert within hours and provide relevant results.

\section{Acknowledgments}

The authors would like to thank the collaboration of the different authorities involved in the management of the case, especially the Consejería de Sanidad, the emergency service, and the veterinarians from GEACAM. The authors would also like to thank everyone that helped in compiling the data for this study. 


\section{Conflict of interest}

None declared.

\section{Authors' contributions}

ACPD: wrote the outbreak report and collaborated in the field actions for management. MV, JM, AE: managed the outbreak, worked in decision making and collaborated to collect data for publication.

\section{References}

1. Abellán García C, Sánchez-Serrano L, Amador R, Rosinha A. Rabies in the iberian peninsula. In: King A, Fooks A, Aubert $M$, and Wandeler A, editors. Historical Perspective of Rabies in Europe and the Mediterranean Basin. Paris: World Organization for Animal Health; 2004. p. 147- 56.

2. Rodríguez Valín E, Sánchez-Serrano L, Díaz García O, Berciano Rodríguez J, Echevarría Mayo J. Rabia Animal en España. Situación en 2012. [Animal rabies in Spain. Situation in 2012]. Boletín epidemiológico Semanal. 2013;21(3):25-34. Spanish.

3. Astorga Márquez R. La Rabia: Revisión sobre aspectos zoonósicos y Policía Sanitaria. [Rabies: Review of zoonotic aspects and public health policy]. Información Veterinaria. 2002. Spanish.

4. Gautret $P$, Ribadeau-Dumas F, Parola P, Brouqui $P$, Bourhy H. Risk for rabies importation from North Africa. Emerg Infect Dis. 2011;17(12):2187-93. Available from: http://dx.doi.org/10.3201/ eid1712.110300 PMID:22185767

5. de Agricultura M, Alimentación y Medio A. Ministerio de Sanidad, Servicios Sociales e Igualdad (MSSSI), Ministerio de Economía y Competitividad. Plan de contingencia para el control de la rabia en animales domésticos en España. [Contingency plan for the control of rabies in domestic animals in Spain]. Madrid: MSSSI; 2012; Spanish Available from: http://www.msssi.gob.es/profesionales/saludPublica/ sanidadExterior/docs/planContingencia control rabia animales domesticos esp rev3 Junio2013.pdf

6. Napp S, Casas M, Moset S, Paramio JL, Casal J. Quantitative risk assessment model of canine rabies introduction: application to the risk to the European Union from Morocco. Epidemiol Infect. 2010;138(11):1569-80. Available from: http:// dx.doi.org/10.1017/S0950268810000415 PMID:20199698

7. Direction Générale de l'Alimentation, Ministère de l'Agriculture et de la Pêche. Immediate notification: Reoccurrence of a listed disease: Rabies. Paris: World Organization for Animal Health; 2013; Available from: http://www.oie.int/wahis 2/public wahid.php/Reviewreport/Review?page_refer=MapFullEventRep ort\&reportid=14333

8. van Rijckevorsel GG, Swaan CM, van den Bergh JP, Goorhuis A, Baayen D, Isken L, et al. Rabid puppy-dog imported into the Netherlands from Morocco via Spain, February 2012. Euro Surveill. 2012;17(10): $\mathrm{pii}=20112$. Available from PMID:22433596

9. World Organization for Animal Health (WAHID) interface. Disease information. List of countries by sanitary status at 2012. Paris: WAHID; [Accessed: April 2014]; Available from: http://www.oie.int/wahis_2/public/wahid.php/ Diseaseinformation/statuslist

10. Consejería de Agricultura. Orden de 21/06/2012, de la Consejería de Agricultura, por la que se dictan las normas obligatorias para la vacunación antirrábica y la desparasitación equinocócica de los cánidos domésticos de Castilla-La Mancha. [Order of 21 Jun 2012 of the Department of Agriculture establishing mandatory standards for rabies vaccination and echinococcal deworming of domestic dogs of Castilla-La Mancha]. Official Journal of Castilla-La Mancha. Toledo: Junta de Comunidades de Castilla-La Mancha; 2012; Spanish. Available from: http://docm.jccm.es/portaldocm/ descargarArchivo.do?ruta=2012/06/28/pdf/2012_9346. pdf\&tipo=rutaDocm

11. European Commission. Regulation (EC) No $998 / 2003$ of the European parliament and of the Council of 26 May 2003 on the animal health requirements applicable to the noncommercial movement of pet animals and amending Council Directive 92/65/EEC. Official Journal of the European Union. Luxembourg: Publications Office of the European Union. 13 Jun 2005:L 146. Available from: http://ec.europa.eu/food/animal/ liveanimals/pets/reg_998_2003_en.pdf

12. de Sanidad de la Producción Agraria DG, de Agricultura M. Alimentación y Medio Ambiente (MAGRAMA). Caso de rabia en un perro notificado el 05.06.2013 por Castilla La
Mancha. Resumen a 6/06/2013. [Case of rabies in a dog notified on 5 June 2013 by Castilla-La Mancha. Summary on 6 June 2013] Madrid: MAGRAMA; 2013; Spanish. Available from: http://www.colvetourense.es/rubberdoc/ da4a9366cd2c2228ec661c8bc8c3b131.pdf

13. de Sanidad de la Producción Agraria DG, de Agricultura M. Alimentación y Medio Ambiente. Immediate notification. Reoccurrence of a listed disease. Rabies. Paris: World Organization for Animal Health; 2013; Available from: http:// www.oie.int/wahis 2/public/wahid.php/Reviewreport/ Review?reportid $=13565$

14. de Sanidad M, Sociales e Igualdad S. (MSSSI). Declaración de foco de rabia canina en Toledo. [Declaration of a focus of canine rabies in Toledo]. Madrid: MSSSI; 2013. Spanish. Available from: http://www.msssi.gob.es/profesionales/ saludPublica/ccayes/alertasActual/docs/evRabTo_25_6 13.pdf

15. Dirección General de Agricultura y Ganadería. Resolución de 19/06/2013, de la Dirección General de Agricultura y Ganadería, por la que se ordena publicar la Resolución de 17/06/2013 relativa a la ejecución de la medida sanitaria obligatoria de sacrificio del perro con microchip 941000014033587 conforme al plan de contingencia para el control de la rabia y la Ley $8 / 2003$, de 24 de abril, de Sanidad Animal. [Resolution of 19 Jun 2013 of the Directorate General of Agriculture and Livestock, which publishes the resolution of 17 Jun 2013 on the implementation of the compulsory public health measure of sacrificing the dog with the microchip 941000014033587 according to the contingency plan for the control of rabies and the Law 8/2003 of 24 April of Animal Health]. Official Journal of Castilla-La Mancha. Toledo: Junta de Comunidades de Castilla-La Mancha; 2013; Spanish. Available from: http://docm.jccm.es/portaldocm/descargarArchivo. do? ruta $=2013 / 06 / 20 / \mathrm{pdf} / 2013$ 7691.pdf\&tipo=rutaDocm

16. de Sanidad M, Sociales e Igualdad S. (MSSSI). Finalización del periodo en nivel de alerta 1 tras la detección de un foco de rabia canina en España. [End of the period of alert level 1 following the detection of an outbreak of canine rabies in Spain]. Madrid: MSSSI; 2013; Spanish. Available from: http:// www.msssi.gob.es/profesionales/saludPublica/ccayes/ alertasActual/docs/Fin_nivel_de_alerta_1_dic_2013.pdf.

17. de Sanidad de la Producción Agraria DG, de Agricultura M. Alimentación y Medio Ambiente. Follow-up report (final report). Rabies. Paris: World Organization for Animal Health; 2013 Available from: http://www.oie.int/wahis_2/public/wahid.php/ Reviewreport/Review?reportid $=14566$

18. Calistri P, Iannetti S, Danzetta ML, Narcisi V, Cito F, Sabatino DD, et al. The components of 'One World - One Health' approach. Transbound Emerg Dis. 2013;60(Suppl 2):413. Available from: http://dx.doi.org/10.1111/tbed.12145 PMID:24589096

19. Beran GW, Frith M. Domestic animal rabies control: an overview. Rev Infect Dis. 1988;10(Suppl 4):S672-7. Available from: http://dx.doi.org/10.1093/clinids/10.Supplement_4.S672 PMID:3206079

20. Briggs DJ. The role of vaccination in rabies prevention. Curr Opin Virol. 2012;2(3):309-14. http://dx.doi.org/10.1016/j. coviro.2012.03.007 PMID:22503445

21. Cliquet F, Picard-Meyer E, Robardet E. Rabies in Europe: what are the risks? Expert Rev Anti Infect Ther. 2014;12(8):905-8. 10.1586/14787210.2014.921570

22. Bonizzi L, Guarino M, Roncada P, Colosio C. [Assessment and prevention of zoonoses: "one health approach"]. G Ital Med Lav Ergon. 2013;35(4):307-9. Available from: PMID:24303718 